\title{
ChIRONOMids of THE ARAL SEA
}

\author{
Larisa Nazarova ${ }^{1,2}$ \\ ${ }^{1}$ Kazan State University, Russia (permanent). Email: nazarova larisa@mail.ru \\ ${ }^{2}$ Alfred-Wegener-Institute for Polar and Marine Research. Potsdam, Germany (current)
}

The Aral Sea once was the fourth-largest lake in the world, but since about 1957 has been drying up as more and more water is diverted to irrigate cotton and other thirsty crops. The Aral Sea is a terminal lake in an arid region, therefore is affected by environmental changes in the catchment area more than other lakes.

In spite of the long history of hydrobiological investigations in the Aral Sea, no special taxonomic study of chironomids has been performed. The group has been taken into account mainly as one element in productivity estimations of benthic communities as a food source for fishes. Here we present an overview of the available Russian literature containing information on the chironomid fauna of the Aral Sea.

Behning (1936) reported the Sea, especially the muddy bottom of its northern part, to be inhabited by massive quantities of Chironomus behningi Goetghebuer. Larvae of this species numbered up to 1630 individuals $/ \mathrm{m}^{2}$ and $25-30 \mathrm{~g} / \mathrm{m}^{2}$; its different life stages formed the main food source for the members of various fish and bird species. Behning illustrated the rear end of the larva, and identified the latter as the form "designated by the larvae researchers as >Chironomus Plumosus Reductus<" (op.cit.: legend to Fig. 1).

From the mid 1940s to the end of the 1970s, macrozoobenthos was investigated regularly across all of the Aral Sea. As a result, species composition and quantitative characteristics of the community at that relatively stable stage of the lake's development and during the initial phases of its salinization are relatively well documented (e.g. Yablonskaya 1960a, 1960b; Yablonskaya et al. 1973; Andreeva 1978, 1983, 1989). However, data on macrobenthos species richness during that time vary rather widely: from
50 to 95 species according to different authors (Khusainova 1958; Zenkevich 1963). In any case, it is clear that species lists were not complete. Moreover, the taxonomy of most groups, especially of the Chironomidae, has changed considerably since then, which makes comparisons of those investigations with later ones very difficult.

Surveys of benthic communities of the Karabaili Archipelago (southeastern part of the Aral Sea) in the summer seasons of 1951 and 1954 (Dengina 1959) showed chironomid distribution to be strongly limited by salinity levels. Maximal abundance and biomass were found in those parts of the archipelago where salinity did not exceed $20 \%$. The most abundant species were reported under the contemporary larval names Tanytarsus gr. gregarius, Cryptochironomus gr. defectus, Tendipes (Chironomus) f.l. plumosus, T. (C.) f.l. plumosus-reductus, T. (C.) f.l. bathophilusreductus, Cricotopus gr. silvestris, and Procladius sp. In salinity above $20 \%$, only T. (C.) f.l. salinarius, Tanytarsus gr. exiguus and Cryptochironomus sp. were found.

The most detailed description of the Aral Sea chironomid fauna so far has been presented by Konstantinov and Belyanina (1974), who summarised results of previous investigations and gave an illustrated identification key as well as some species-specific information on ecology and habitat. The larvae of 18 chironomid species, mostly Chironomini, are recorded as inhabiting the Aral Sea. The drawings and morphological characteristics facilitate determination of the corresponding species names in current taxonomy.

A rare case of a karyological study in the area is the description of the karyotype of Chironomus behningi from the Aral Sea (Belyanina and Kolosova 1979). 
Carnivorous invertebrates - in Chironomidae: Pelopia vilipennis Kieffer, Procladius ferrugineus Kieffer, and Cryptochironomus gr. defectus - were never numerous in the benthos of the Aral Sea, but by the beginning of the 1980s under pressure from the increasing salinization, even these few species had disappeared (Andreeva and Andreev 1990).

Compared to earlier years (before 1971), in 19761977 and 1980, when salinity rose above $15 \%$, only 2 species remained in the lake's bays: $C h$. salinarius and Ch. halophilus (Andreeva 1989). Other species disappeared from the benthic communities (Aladin and Potts 1992). At the end of the 1980s, a drastic lowering of the Sea level made further studies in the open sea impossible. Rare investigations took place in the littoral zones only (Filippov 1995). In 1990, the productivity of benthic assemblages in the coastal zone of the Small Aral Sea was found to be 2.4 times those in the Large Aral Sea (Filippov 2001, 2002). Chironomids, however, were found in the Syr Darya River only and represented by a single freshwater species, Polypedilum nubeculosum Meigen - it was very rare and present in very low numbers only.

Currently, only Chironomus salinarius can be found in the western basin of the lake (Mirabdullayev et al. 2004).

\section{Acknowledgments}

I am grateful to Dr. Martin Spies for his valuable comments, improvements and additions. The investigation was supported by INTAS.

I will be very grateful to everyone sending me any information about investigations of Aral Sea chironomids, references or papers, which are missing, in the presented overview.

Table 1. Chironomid taxa recorded from the Aral Sea.

\begin{tabular}{|c|c|c|}
\hline Recorded as & Reference & $\begin{array}{l}\text { Present estimate (no material studied; names not necessarily } \\
\text { valid nomenclaturally or taxonomically) }\end{array}$ \\
\hline Ablabesmyia gr. lentiginosa Fries. & 9 & Ablabesmyia lentiginosa group sensu Chernovsky (1949) \\
\hline Procladius ferrugineus Kieff. & 14 & Procladius (Holotanypus) ferrugineus (Kieffer, 1918) \\
\hline Procladius $s p$. & 9 & Procladius sp.. sensu Chernovsky (1949) \\
\hline Pelopia vilipennis Kieff. & 5,14 & Tanypus (T.) vilipennis (Kieffer, 1918) \\
\hline Corynoneura sp. Tschern. & 14 & Corynoneura sp. sensu Chernovsky (1949) \\
\hline Cricotopus gr. algarum Kieff. & 9 & Cricotopus (Cricotopus) algarum (Kieffer, 1911) \\
\hline Cricotopus gr. silvestris $\mathrm{F}$. & 9,14 & $\begin{array}{l}\text { Cricotopus (Isocladius) sylvestris group sensu Chernovsky } \\
\text { (1949) }\end{array}$ \\
\hline Chironomus halophilus Kieff. & $4,11,14$ & Chironomus (C.) aprilinus Meigen, 1818 \\
\hline $\begin{array}{l}\text { Tendipes / Chironomus f. l. bathophilus- } \\
\text { reductus }\end{array}$ & 9 & $\begin{array}{l}\text { ?Chironomus (C.) f. l. bathophilus sensu Chernovsky (1949)? } \\
\text { AND/OR C. (C.) f. l. reductus sensu Chernovsky (1949)? }\end{array}$ \\
\hline Chironomus behningi Goet. & $6,7,14$ & Chironomus (C.) behningi Goetghebuer, 1928 \\
\hline Tendipes / Chironomus f. l. plumosus & 9 & Chironomus (C.) f. l. plumosus sensu Chernovsky (1949) \\
\hline $\begin{array}{l}\text { Tendipes / Chironomus f. l. plumosus- } \\
\text { reductus }\end{array}$ & 9 & $\begin{array}{l}\text { Chironomus (C.) f. l. plumosus-reductus sensu Chernovsky } \\
\text { (1949) }\end{array}$ \\
\hline Chironomus salinarius Kieff. & $4,9,15$ & $\begin{array}{l}\text { ? Chironomus (C.) f. l. salinarius sensu Chernovsky (1949) } \\
\text { ?OR? C. (C.) salinarius Kieffer, } 1915 \text { ? }\end{array}$ \\
\hline Cryptochironomus gr. viridulus F. & 14 & Cladopelma viridulum group sensu Chernovsky (1949) \\
\hline Cryptochironomus gr. defectus & 9,14 & Cryptochironomus defectus group sensu Chernovsky (1949) \\
\hline Cryptochironomus sp. & 9 & Cryptochironomus sp sensu Chernovsky (1949) \\
\hline Cryptochironomus supplicans Meig. & 14 & Cryptochironomus supplicans (Meigen, 1830) \\
\hline Limnochironomus nervosus Staeg. & 14 & Dicrotendipes nervosus (Staeger, 1839) \\
\hline Glyptotendipes gripekoveni Kieff. & 9,14 & Glyptotendipes (G.) cauliginellus (Kieffer, 1913) \\
\hline Glyptotendipes glaucus Mg. & 14 & Glyptotendipes (G.) glaucus (Meigen, 1818) \\
\hline Cryptochironomus gr. conjungens & 14 & $\begin{array}{l}\text { Microchironomus conjungens group sensu Chernovsky } \\
\text { (1949) }\end{array}$ \\
\hline Polypedilum nubeculosum Meig. & 10 & Polypedilum (P.) nubeculosum (Meigen, 1804) \\
\hline Polypedilum gr. scalaenum Schr. & 14 & $\begin{array}{l}\text { Polypedilum (Tripodura) scalaenum grp. sensu Chernovsky } \\
\text { (1949) }\end{array}$ \\
\hline Tanytarsus gr. lauterborni Kieff. & 9 & Paratanytarsus lauterborni group sensu Chernovsky (1949) \\
\hline Tanytarsus gr. exiguus Joh. & 9,14 & Rheotanytarsus exiguus group sensu Chernovsky (1949) \\
\hline Tanytarsus gr. gregarius Kieff. & 9,14 & Tanytarsus gregarius group sensu Chernovsky (1949) \\
\hline Tanytarsus gr. lobatifrons Kieff. & 14 & Tanytarsus lobatifrons group sensu Chernovsky (1949) \\
\hline
\end{tabular}




\section{References}

[1] Aladin, N.V. and Potts, W.T.W. 1992. Changes in the Aral Sea ecosystems during the period 1960-1990. - Hydrobiologia 237: 67-79.

[2] Andreeva, S.I. 1978. Zoobenthos Aralskogo morja (Zoobenthos of Aral Sea). In Biological basis of fisheries in waters of Middle Asia and Kazahstan. Proceedings of the conference, Frunze: Ilim, 13-14.

[3] Andreeva, S.I. 1983. Macrobenthofauna Aralskogo morja v sovremennyh uslovijah (Macrobenthofauna of Aral Sea in modern conditions). In Biological basis of fisheries in waters of Middle Asia and Kazahstan. Proceedings of the conference, Tshkent: Fan, 48-49.

[4] Andreeva, S.I. 1989. Macrozoobenthos Aralskogo morja $\mathrm{v}$ nachalnyi period ego osolonenija (Macrozoobenthos of Aral Sea at the primary stage of its salinization). Proceedimgs of Zoological Institute, Academy of Scences of USSR 199: 53-82.

[5] Andreeva, S.I., and Andreev, N.I. 1990. Trophic structure of benthic communities in Aral Sea under conditions of changed regime. Soviet Journal of Ecology 21: 94-98.

[6] Behning, A. 1936. Miscellanea aralo-caspica. Internationale Revue der gesamten Hydrobiologie und Hydrographie 33: 241-249.

[7] Belyanina, S.I. and Kolosova, T.A. 1979. Kariotyp Chironomus behningi iz basseina Aralskogo morja (Caryotype of Chironomus behningi from the Aral Sea basin). - Cytologia 29(6): 1103-1106.

[8] Chernovsky, A.A. 1949. Opredelitel' lichinok komarov semeistva Tendipedidae (Identification of larvae of the midge family Tendipedidae). - Opredeliteli po faune SSSR 31: 1-186.

[9] Dengina, R.S. 1959. Benthos of Karabaili Archipelago of Aral Sea. Materials on Investigations of Aral Sea. Works of Laboratory of Limnology of Academy of Science of USSR. - Publications of Academy of Science of USSR. Moscow-Leningrad 8: 2383.

[10] Filippov, A.A. 1995. Makrozoobentos pribrezhznoi zony severnoy chasti Aralskogo Morja v sovremennyh polygalinnyh uslovijah: chislennost', biomassa, prostranstvennoe raspredelenie (Macrozoobentos of littoral zone of Northern part of Aral Sea in modern polyhaline conditions: abundance, biomass, spatial destribution). - Russian Academy of sciences. Proceedings of the Zoological Insitute. St. Peterburg 262: 103-166.

[11] Filippov, A.A. 2001. Makrozoobentos Malogo Aralskogo Morja (Macrozoobentos of the Small Aral Sea) Biologia morya. Vladivostok. 27 (6): 453-455.

[12] Filippov, A.A. 2002. Productivity of the Aral Sea benthic communities. - Oceanology 42 (1): 91-98.

[13] Khusainova, N.A. 1958. Biologicheskie osobennosti nekotoryh massovyh donnyh bespozvonochnyh Aralskogo morya (Biological peculiarities of some benthic fodder invertebrates of the Aral Sea). Kazakh University publisher. Alma-Ata. 1-116.

[14] Konstantinov, A.S. and Belyanina, S.I. 1974. Otryad Dvukrylye, Diptera. Semeistvo Chironomidae (Order two-winged insects, Diptera. Family Chironomidae). Pp. 228-236 in: Mordukhai-Boltovskoi, F.D. (ed.), Atlas bespozvonochnykh Aralskogo morya (Atlas of Aral Sea Invertebrates). Pishchevaya promyshlennost, Moskva.

[15] Mirabdullayev, I.M., Joldasova, I.M., Mustafaeva, Z.A., Kazakhbaev, S., Lyubimova, S.A. and Tashmukhamedov, B.A. 2004. Succession of the ecosystem of the Aral Sea during its transition from oligohaline to polyhaline water body. - Journal of Marine Systems 47: 101-107.

[16] Yablonskaya, E.A. 1960a. Sovremennoe sostojanie zoobentosa Aralskogo Morja (Current state of the zoobenthos of Aral Sea). Proceedings of VNIRO, 43(1): 115-149.

[17] Yablonskaya, E.A. 1960b. Kormovaja baza ryb Aralskogo morja i ee ispol'zovanie (Food base of Aral Sea and its use). - Proceedings of VNIRO, 43(1): 150-176.

[18] Yablonskaya, E.A., Kortunova, T.A. and Gavrilov G.B. 1973. Mnogoletnie izmenenija bentosa Aralskogo morja (Long term changes in benthos of the Aral Sea). - Proceedings of VNIIRO, 80 (3): 147-158.

[19] Zenkevich, L.A. 1963. Biologiya morey SSSR (Biology of the seas of the USSR). Acad. Science Publ. House, Moscow, 739 p. 